of supplies might occasionally mean something very like starvation. Where there are any roads, these are but trails, often more than half overgrown, so that progress is apt to be slow and laborious, difficult swamps and swollen rivers have to be crossed, while mordant insects, mosquitoes and flies, are at times almost intolerable. So notwithstanding the charms of the scenery-bold peaks, fine glaciers, forest-clad slopes, and almost numberless lakelets of rare beauty-travel in the Canadian Rockies is not to be recommended to the habitués of Interlaken or Luchon. Until the Switzerland of Canada is developed-as before long it certainly will be--it can only be explored by hardy and vigorous travellers.

Game, as we have said, is scarce, but the bighorn (Ovis Canadensis) and the Rocky Mountain goat (Haploceros montanus) occur perhaps about as often as chamois in the Swiss Alps, and bears-black, brown and grizzly-are occasionally seen. Geese, ducks, and three kinds of grouse sometimes vary the menu, but evidently the district will hardly be tempting to sportsmen who desire "big bags." Neither do the rocks appear attractive to the palæontologist. The specimens brought back by Dr. Collie were rarely fossil- photographs, which enable us to realise the beautiful scenery of this unfrequented land, and its topography is made clear by a map constructed from the authors' surveys. That is such as we might have expected-long troughs parallel with the general trend of the strata being connected by shorter transverse glens, as can be seen, on a smaller scale, in some parts of the Alps. In consequence of this, the Canadian Pacific Railway, as is well known, descends, west of the watershed, into a valley belonging to the Columbia system, then, after crossing a spur, strikes the same river flowing in an opposite direction, and after another mount descends to follow the Fraser River to the coast. Well illustrated and written in an attractive style, the book records a series of journeys, not always without risk, and throws much light on the geography of a region many parts of which have hitherto been very imperfectly known.

T. G. Bonney.

\section{SCIENCE AND THE ARMY.}

MANY of our readers may have seen a brief preliminary official notice of the proposals of the War Office for the reform of military education. These proposals are so astonishing, in view of the facts of the case, that we take an early opportunity of directing attention to them.

There is to be, first, a qualifying test. It is intended that this shall take the form of a "leaving certificate," but in view of the probable difficulty of organising a suitable leaving examination for a long while, there seems reason to fear that, at first, this qualifying part may take the form of a special examination, which all must pass, but which will not otherwise affect the final result. This qualifying part is to consist of :- (I) English, (2) history and geography, (3) mathematics, (4) French or German, (5) either (a) Latin or Greek, or (b) science.

Then there is to be a competitive examination, in which (I) English, (2) French or German, and (3) mathematics i. will be compulsory for Woolwich candidates; and English and either French or German for Sandhurst candidates. In this examination Woolwich candidates may also offer any two

FIG. I.-Mount Forbes from the F.ast. From "Climbs and Exploration in
by H. E. M. Stutfield and Prof. J. Norman Collie.

iferous, even when examined under the microscope. Mr. Whymper had, on the whole, a similar experience in his explorations near and to the south of the railway, so that either subsequent mineral changes have obliterated the traces of organisms or the region in past ages was not rich in life. Dr. Collie gives an illustration of objects resembling tree trunks high up on Mount Murchison-possibly the stems of some giant alga--and picked up limestone pebbles with corals, probably Devonian or Carboniferous, in the bed of the Bush River. A few specimens contained traces of organisms, some perhaps foraminifera (misprinted foraminiferae), with an ostracod (misprinted ostreod); one slab showed badly preserved trilobites, probably Lower Cambrian, described by Dr. H. Woodward, and the journey of Igor was rewarded with some remarkable tracks and other markings from Desolation Valley, south of the railway, not far from Laggan (see the Geological Magazine for July last).

The book is well illustrated by numerous reproduced

$$
\text { NO. I } 778 \text {, vOL. 69] }
$$
of mathematics ii., science, history, French, German, Latin, Greek; and Sandhurst candidates may also offer any two of mathematics i. or mathematics ii., science, history, French, German, Greek, Latin.

The more closely we look into the probable effect of these proposals the more clearly does it appear that, under this new scheme, experimental science scems certain, by the light of past experience, to become a negligible quantity in the training of most officers. Those who read the report of the Army Education Committee published in March, I902, may remember that the head master of Eton during the examination of a witness expressed confidently the opinion that, if Latin and science should be brought into competition in these examinations, " the science will kill the Latin." Even Dr. Warre, however, does not expect this to happen just yet, for he added, " eventually." Unfortunately for this position, we do not merely want to get a good system of army education eventually, but to get one as soon as possible, 
and the figures which we quote below show how unlikely we are to get such a system under the scheme now put forward, if it be admitted, to adopt a statement taken from the report of the same committee, that experimental science, i.e. chemistry and physics treated experimentally, is an essential part of a sound general education. In the outlined scheme now before us-as stated above-science comes into the education of the candidates in the qualifying part as an alternative for Latin or Greek, that is to say, practically speaking, for Latin: and again in the conpetitive part as an alternative for Latin, French, history, \&c. Now boys at school begin Latin at say eight or nine years of age. They probably rarely begin the experimental science proposed before thirteen or fourteen. If the candidates are to do a three years' course in chemistry and physics, as suggested, they must begin it at fourteen or sooner, in order to be ready for the qualifying part at, say, seventeen, which seems likely to be about the age at which we may expect most candidates will take this part. This means that at about fourteen the choice must be made between science and Latin.

But at fourteen a candidate will have studied Latin, French, \&c., for years. He, his masters and his parents will know a good deal about his prospects in these subjects. Whilst, from what we have said, it is obvious that in most cases they will know nothing about his prospects in science at that age. Can it be doubted that nearly all the cleverer boys, and most even of those whose abilities are second rate, will neglect science at every stage-that, as a rule, only those who are really bad at Latin will get any science? Again, is it reasonable to suppose that candidates whose early education has included no experimental science will at the eleventh hour give up one of the subjects in which they are somewhat advanced, and take to a subject in which they are untried and untrained? Must it not happen that the average officer of the future will know nothing of, and care nothing for, science or its methods, be incapable of appreciating its importance to his profession, and incapable, even, of using the knowledge of others from ignorance of their language and methods of thought? This scheme must result most disastrously in its effect on the army and on the schools.

It has been suggested that the parents will select and insist on the science. We do not believe it. There is a strongly flowing current in favour of science among the parents. That is true. But how can any reasonable parent be expected to insist on his son taking up the subject which seems least likely to conduce to success in a competition of vital importance to him?

But this question is not really a matter of opinion at all.

Some years ago science, in both Woolwich and Sandhurst competitions, had to compete in a somewhat similar way with several other subjects which are begun earlier than the experimental science at schools, and on conditions which were, we think, not so very much more unfavourable than those now proposed. From computations that have been made for us, we find that at that time one successful Sandhurst candidate in twelve ventured to offer experimental science For Woolwich, even, though there were well-known advantages in starting at the Royal Military Academy with a scientific training, which no doubt will still exist, the proportion who offered science was only 22 per cent., or say one in five, of the whole.

As the majority of the candidates will continue for some time to come to be derived from the same classes as in the past, why should we expect a more favourable result now? Some years ago Sir Henry Roscoe and others came forward as the champions of science, and, aided by the head masters of Rugby, Cheltenham, Clifton, and other schools, and by insistently directing attention to these and similar facts, presently secured a more reasonable system in many respects. No doubt the science arrangements made then need revision now in many of their details. But the need for science training among our officers, the need for a fuller appreciation among them of the part it plays, the absolute need to start a training in science, as in languages and mathematics, at an early stage of a boy's training; and, above all, the importance of not teaching young officers to regard it as unimportant by neglecting it at the schools or afterwards, were never greater than at this moment. Who among our leaders in science will come forward in this fresh emergency?

\section{PROF. ALEXANDER ROLLETT.}

PROF. ALEXANDER ROLLETT, of the University of Graz, the eminent physiologist, died on October $\mathrm{I}$ at the age of sixty-nine. His name, though not associated with any particularly brilliant discovery, is well known to science as that of a diligent and successful worker.

Descended from a family of doctors, both his father and grandfather having been more or less distinguished physicians in Baden, near Vienna, Alexander Rollett commenced his medical studies in the dawn of the great era of physiological science under the guidance of Carl Ludwig and of Ernst Brücke, then newly appointed professor of physiology in Vienna.

In $185^{8}$, having completed his course of studies, Rollett became Brücke's assistant, and in 1863 was appointed to the professorship in Graz, which he retained until his death. Like his great masters, Rollett's investigations extended to widely different subjects, but by preference to problems that involve the use of histological methods. His principal researches may be summed up under no less than four distinct headings :-chemistry and histology of connective tissue, chemistry and histology of blood, histology and physiology of muscle, and work on sight and other senses. Three of these different subjects Rollett subsequently treated at length in several standard publications.

We find Rollett first studying the composition and structure of the connective tissues, and demonstrating that mucine is a prime constituent of these substances. His work on this subject, and especially on the cornea, he later on embodied in the corresponding chapters of Stricker's " Handbuch der Gewebelehre." He then turned his attention to the chemical and histological properties of the blood, and it was he that first performed the well-known experiment of " laking " blood by alternate freezing and thawing, and by repeated discharges of electricity. The theory of the " stroma " of the red corpuscles is likewise founded largely on Rollett's observations. By these and other discoveries he attained the rank of a prime authority on the physiology of blood, so that when Hermann edited his wellknown "Handbuch," the chapter on blood fell to Rollett's share.

On the intricate subject of the structure of striated muscle Rollett brought to bear his powers of histological analysis, and added new comparative data of value by his observations on the muscles of bats, of insects, and of other invertebrates. At a much later period Rollett again approached the study of muscle from a physiological point of view, and published important observations on the velocity of the contraction wave and on exhaustion phenomena. On the

$$
\text { No. I778, vor. 69] }
$$

